\title{
Treatment options and reproductive outcome for adenomyosis-associated infertility
}

\author{
Ilaria Soave, Jean-Marie Wenger, Nicola Pluchino \& Roberto Marci
}

To cite this article: Ilaria Soave, Jean-Marie Wenger, Nicola Pluchino \& Roberto Marci (2017):

Treatment options and reproductive outcome for adenomyosis-associated infertility, Current Medical Research and Opinion, DOI: 10.1080/03007995.2017.1393404

To link to this article: http://dx.doi.org/10.1080/03007995.2017.1393404

Accepted author version posted online: 19 Oct 2017.

Submit your article to this journal \lceil

Q View related articles $₫$

View Crossmark data $\asymp$ 


\title{
Treatment options and reproductive outcome for adenomyosis-associated infertility
}

\author{
Ilaria Soave ${ }^{\mathrm{a}}$, Jean-Marie Wenger ${ }^{\mathrm{b}}$, Nicola Pluchino ${ }^{\mathrm{b}}$, Roberto Marci ${ }^{\mathrm{a}, \mathrm{b}}$ \\ ${ }^{a}$ Department of Morphology, Surgery and Experimental Medicine, University of Ferrara, via Borsari 46, 44100, \\ Ferrara, Italy \\ ${ }^{\mathrm{b}}$ Division of Obstetrics and Gynecology, University Hospital of Geneva, Boulevard de la Cluse 30, 1205, Geneva, \\ Switzerland.
}

Corresponding Author: Roberto Marci

Address: Boulevard de la Cluse, 30, 1205, Genève, Suisse

Email: roberto.marci@unife.it

Tel: 00393386960872

Transparency Statement

Declaration of funding

This manuscript was not funded

Declaration of financial/other interests

The authors have no relevant affiliations or financial involvement with any organization or entity with a financial interest in or financial conflict with the subject matter or materials discussed in the manuscript. This includes employment, consultancies, honoraria, stock ownership or options, expert testimony, grants or patents received or pending, or royalties.

\section{Acknowledgments}

None. 


\section{Abstract}

Adenomyosis is a benign gynecological disease mostly diagnosed in the fourth and fifth decades. The recent improvement of the diagnostic tools and a better understanding of the pathology allowed clinicians to postulate a possible relationship between adenomyosis and infertility and to diagnose it in younger asymptomatic women during infertility work-up. The exact link between adenomyosis and infertility is still not fully established, but recent studies suggest a possible negative effect on female fertility. The purpose of this article is to review the different theories regarding the possible correlation between adenomyosis and infertility and to discuss the treatment options and the final reproductive outcome after the treatment.

Keywords: adenomyosis; infertility; uterus-sparing surgery; adenomyoma; assisted reproduction; IVF 


\section{Introduction}

Adenomyosis is a benign gynaecological disease characterized by the presence of endometrial glands and stroma surrounded by hypertrophic and hyperplastic smooth muscle deep within the myometrium ${ }^{1}$. Different manifestation of adenomyosis could be distinguished: endometrial implants can either be interspersed within the myometrium as numerous isolated ectopic islands of glandular and stromal tissue (diffuse form) or can be organized in a well-circumscribed nodular lesion (focal form or adenomyoma). Macroscopically, adenomyosis is responsible for a globular and cystic enlargement of the uterus, due to the presence of myometrial cysts filled with red blood cells and siderophages ${ }^{2}$. Microscopically, endometrial glands and stroma must be located within the myometrium deeper than $2,5 \mathrm{~mm}$ from the endometrial-myometrial interface ${ }^{3-5}$, but a common histologic consensus regarding the depth of invasion is lacking. In fact another often used criterion includes endometrial glands extended 1 to $3 \mathrm{~mm}$ below the endometrial layer or foci situated deeper than $25 \%$ of the total thickness of the myometrium ${ }^{6,7}$. Because of a lack of an agreed-upon terminology, its incidence is generally underestimated and its prevalence varies significantly between studies (from $5 \%$ to $70 \%)^{8}$.

Adenomyosis is characterized by an alteration in the endometrium-myometrium interface, the so called Junctional Zone (JZ). Current imaging diagnosis is carried out through TV-US (Transvaginal Ultrasound), given its low execution cost, the high tolerability and the recent improvement of the technique itself (high-resolution images, Doppler) ${ }^{9}$. At the present time there's a lack of consensus on the criteria that should be used for the diagnosis. However, it seems that the presence of one or more of the following sonographic findings on 2D TV-US (two-dimensional Transvaginal Ultrasound) enables the diagnosis with satisfactory accuracy ${ }^{10,11}$ : i) globular uterine configuration; ii) anterior-posterior asymmetry of uterine walls unrelated to leiomyoma; iii) heterogeneous myometrial echotexture; iv) poorly defined endometrial-myometrial interface; v) myometrial echogenic linear striation (acoustic shadows not arising from leiomyoma or other echogenic foci); vi) myometrial cysts; vii) diffuse spread of small vessels into the myometrium. Another sonographic finding was recently added to the list by an Italian study group: "the corpus uteri is flexed backwards, the fundus of the uterus faces the posterior compartment and the cervix is directed frontally towards the bladder". The sign, called "the question mark of the uterus", showed high sensitivity and specificity (92\% and $75 \%$ respectively) ${ }^{12}$. The advent of 3D US-TV (threedimensional Transvaginal Ultrasound) allows the direct visualization of endometrial protrusion into the myometrium. As for the 2D US-TV nowadays there is no consensus on 3D ultrasound diagnostic criteria either. However, the main findings are the JZ thickness and the infiltration of the 
hypoechoic JZ by hyperechoic endometrial tissue. A further advantage of this technique is the view of the adenomyotic lesions in three planes, allowing an accurate mapping of the myometrial infiltration, making conservatory surgery more accurate ${ }^{13,14}$. Moreover, the use of 3D US-TV with color Doppler may help in differentiating adenomyosis from leiomyomas, another commom gynecological disorder with similar clinical symptoms and signs. A recent study measured blood flow impedance (Pulsatility Index, Resistive Index, Maximum Velocity) around and within the lesions ${ }^{15}$. The presence of "central vascularity" and "ill defined junctional zone in 3D ultrasound" appears to have a high sensitivity and specificity (95.6\% and $93.4 \%$, respectively) in diagnosing adenomyotic foci. MRI is a non-invasive technique, traditionally considered more accurate than TV-US in the diagnosis of adenomyosis, even if a recent study showed comparable sensitivity and specificity $^{16}$. Given its high costs, it is often performed only in selected cases (e.g. concomitant presence of leyomyomas, polypes, endometriosis). MRI allows the identification of the JZ as a low signal banding in T2-weighed images when compared to myometrium or endometrium. In 2001 Bazot et al., proposed some diagnostic criteria, which are still taken into account: i) high-signal intensity spots in the myometrium; ii) JZ thickness $>12 \mathrm{~mm}$ (diffuse or focal) and/or low signal intensity ill-defined lesions; iii) $\mathrm{JZ}$ thickness/myometrium thickness $>40 \%{ }^{10}$.

In the International Classification of Disease codes, adenomyosis is thought to be a specific form of endometriosis and is defined as "endometriosis of the uterus". Indeed, women with severe endometriosis (American Fertility Society stage IV) are often diagnosed with adenomyosis with higher incidence and deeper uterine wall invasion when compared with other stages $(42.8 \%$ vs $29.4 \%)^{17}$. Nevertheless, patients with adenomyosis present different clinical features than those with endometriosis. Women with endometriosis are generally young, nulliparous and often a mother or a sister is also affected. On the contrary, adenomyosis is mostly diagnosed in the forth and fifth decades and is associated with early menarche, multiparity and history of miscarriage $e^{6,18,19}$. Consequently, adenomyosis was thought to be a disease entity different from endometriosis. However, recent studies pointed out that adenomyosis can coexist with endometriosis in younger women, suggesting a common pathogenesis ${ }^{20}$ and that it could responsible for implantation failure in patients with endometriosis ${ }^{21}$. Patients affected by adenomyosis generally complain about menometrorrhagia and pelvic pain, but given the fact that many women delay their pregnancy until their late 30 s or 40 s the relation between adenomyosis and infertility is becoming a focal topic. The exact link is still not fully established, but recent studies suggested a possible negative effect on female fertility. By systematically reviewing the available evidence, this paper discuss the current medical and surgical uterus-sparing treatment options in infertile women and the fertility outcome after the treatment. 


\section{Material and methods}

We search Pubmed for articles published in the English language with the use of the following MeSH search terms: "adenomyosis" combined with "treatment" and "fertility outcome" with the restriction to the human species. Titles and abstracts were examined by two reviewers ( I.S. and R.M.) and full articles that met the selection criteria were retrieved. A manual search of review articles and cross-references completed the search. All selected articles were assessed for study design, patients characteristic, diagnosis of adenomyosis, type of treatment, post-treatment rates of conception, full-term pregnancy and completeness of information of the data sets.

\section{PATHOPHYSIOLOGY OF INFERTILITY/SUBFERTILITY}

Even if adenomyosis is usually diagnosed in the forth and fifth decades, the recent improvement of the diagnostic tools and a better understanding of the pathology allowed clinicians to postulate a possible relationship between adenomyosis and infertility and to diagnose it in younger asymptomatic women during infertility work-up, making its treatment even more challenging ${ }^{22,23}$. The exact link is still under debate ${ }^{24,25}$. Several theories regarding the possible correlation between adenomyosis and infertility have been proposed.

\section{Anatomical distortion}

The exact anatomical mechanism by which adenomyomas may have a detrimental effect on reproduction are still unknown. Obstruction of the tubal ostia and impaired sperm migration and embryo transportation caused by an anatomical distortion of the uterine cavity may be the principal determinants (Figure 1). Several studies have investigated how submucosal and intramural fibroids in the presence of intrauterine anatomical abnormalities are associated with infertility ${ }^{26,27}$.

\section{$\underline{\text { Uterine dysperistalsis }}$}

The abnormal contractility, consequence of the altered architecture of the JZ myometrium, may impare both implantation and sperm transport ${ }^{28}$. A study published in 2006 showed how adenomyosis is associated with impeded hyperperistaltic and dysperistaltic uterotubal transport capacity $^{29}$. The study population included 41 infertile patients with endometriosis (laparoscopically proved) and patent tubes, 35 of them with additional signs of adenomyosis. 99m-Tc-labelled macroalbuminaggregates with a size of 5-20 $\mu \mathrm{m}$, diluted with $2 \mathrm{ml} 0.9 \%$ saline solution, were placed into the posterior vaginal fornix and scans with a gamma camera (directly after 
administration and at various time intervals) were taken. Fertile women showed a uni- and ipsilateral transport with concentration of radioactivity on the side of the dominant follicle. Otherwise in patients affected by diffuse adenomyosis in $70 \%$ of the cases the radionuclides remained in the uterine cavity, in $22 \%$ of the patients a contralateral transport was detected and only in $8 \%$ of the women an ipsilateral transport was proved. In addition, some differences at cellular level were found, too. Mehasseb et al. recently concluded that smooth muscle cells of an adenomyotic uterus are ultrastructurally different because they exhibite cellular and nuclear hypertrophy when compared normal uterine smooth muscle cells ${ }^{30}$. This ultrastructural alteration may be responsible for an abnormal uterine contraction, disturbing the uterotubal transport. Furthermore, another element that could explain the altered peristaltic activity is the loss of nerve fibres at the endometrium-myometrium interface associated with adenomyosis ${ }^{31}$.

\section{$\underline{\text { Altered implantation }}$}

Implantation represents a subtle process starting with a controlled invasion of the decidualized endometrium by the early embryo, where proper endometrial development and proliferation are key factors. Thus, any abnormal process interfering with the endometrial proliferative and secretory phases could potentially impair implantation. At the present time, there are no available data regarding atypical endometrial proliferation in women affected by adenomyosis, but altered vascularization and molecular markers have been documented. Ota and Tanaka performed a morphometric analysis of the endometrium in fertile women and in patients affected by adenomyosis $^{32}$. They found that in the first group (fertile women) the mean and total surface area and the total number of capillaries where significantly increased during the secretory phase when compared to the proliferative one. In the second group (women with adenomyosis) there was no difference between the two phases, with values significantly higher in comparison to the fertile group, suggesting an overexpression of regulatory factors involved in the vascular proliferation. At molecular level several anomalies have been described. Li et al. studied the role of matrix metalloproteinasis (MMP-2 and MMP-9) and their relationship with microvessel density (MVD) and with a major mediator of angiogenesis, such as vascular endothelial growth factor (VEGF) ${ }^{33}$. MMPs are enzymes normally expressed in the human endometrium during the menstrual cycle, necessary for extracellular matrix remodeling. The results showed a greater activity of all considered factors, in both eutopic and ectopic endometrium of patients affected by adenomyosis. Furthermore, a positive correlation was found between VEGF and MMP-2/-9 expression and between MVD and MMP-2/-9 expression in the ectopic endometrium, suggesting that MMP-2 and MMP-9 overexpression could contribute to the endometrial invasion of the myometrium and to the 
angiogenetic process. Afterwards Goteri et al. investigated the expression of VEGF and hypoxiainducible factor-1 $\alpha$ (HIF-1 $\alpha$ ) expression and microvessel density (MVD) in eutopic and ectopic endometrium, confirming the possible role of VEGF-mediated angiogenesis in the development of the disease ${ }^{34}$. Improper secretion of cytokines has also been reported, suggesting that an abnormal inflammatory response could also impair fertility. IL-8 represents an important signaling factor that modulates several processes during the menstrual cycle, including endometrial remodeling. Two IL8 receptors have been identified on the surface of human neutrophils (CXCR1 and CXCR2), which are both highly expressed in women with adenomyosis ${ }^{35}$. IL-10 is another inflammatory cytokine, which plays an important role in chronic inflammatory diseases and cancers. Higher levels of IL-10 have been found in both eutopic and ectopic endometrium, possibly leading to an abnormal immunitary response and subsequently to infertility ${ }^{36}$. Another important factor that seems to be involved in the implantation process is the HOXA10 gene, the expression of which seems to be necessary for implantation. In the normal endometrium its cyclic expression is regulated by estrogen and progesterone, with a peak during the window of implantation. In women with adenomyosis the HOXA10 gene expression is significantly diminished during the midsecretory phase, suggesting its possible role in the reduced implantation rate observed in patients affected by adenomyosis ${ }^{37}$. Another "implantation marker" associated with endometrial receptivity is the leukemia inhibitory factor (LIF). Its expression is normally higher in the mid-late secretory phase, but lower levels have been found in the endometrium and in the flushing fluid of women affected by adenomyosis ${ }^{38,39}$. For a successful implantation and for the maintenance of a pregnancy, an intense remodeling of the endometrium is required. This process is called decidualization and includes the expression of factors involved in the suppression of the immune response. Recently Wicherek dosed the serum blood concentration of RCAS1, which is responsible for the inhibition of growth and activation of $\mathrm{NK}$ cells and $\mathrm{T}$ lymphocytes ${ }^{40}$. In fertile women its concentration fluctuates during the menstrual cycle with a peak in the secretory phase, while it remains almost constant in patients with adenomyosis. Another factor, which is overexpressed in patients affected by adenomyosis is the $\mathrm{P} 450$ aromatase, leading to increased local endometrial estrogen production. This overexpression might alter the balance between estrogens and progesterone, with an upregulation of estrogen receptor $\alpha$ (which is normally downregulated by progesterone). This overexpression ends up with a decreased production of integrines (molecules necessary for the successful interaction between embryo and endometrium), compromising the uterine receptivity ${ }^{41}$.

\section{Intrauterine free radicals}

Several enzymes producing or eliminating free radicals are present in the glandular epithelium of 
the endometrium and their concentration varies during the menstrual cycle. Some of these enzymes are the superoxide dismutase (SOD), nitric oxide synthase (NOS), xanthine oxidase (XO), glutathione peroxidase (GPx) and catalase. It is well known that in fertile women SOD and NOS concentration are low during the proliferative phase and increase during the secretory phase ${ }^{42}$. In patients affected by adenomyosis these enzymes are overexpressed, leading to abnormal levels of free radicals (i.e. superoxide, nitric oxide) ${ }^{43}$ that could jeopardize the early embryo, impeding implantation and embryo development and leading to early miscarriage ${ }^{44}$.

A recent review published by Yen et al. summarizes the specific molecular characteristics of the endometrium in uterine adenomyosis and its biochemical microenvironment ${ }^{45}$. Whether adenomyosis is a genetically determined disease or the result of a dysregulated hormonal milieu under the influence of several microenvironmental factors remains to establish.

\section{Effect on IVF treatment}

In the adenomyotic endometrium many endometrial receptivity markers are altered, but none of these has been proven to be predictive of implantation in humans ${ }^{20,25,46}$. Up to now, the only studies that have examined the effect of adenomyosis on natural conception are on animal models (baboons), showing a negative influence even in the absence of endometriosis ${ }^{47}$.

Soares et al. suggested women requiring oocytes donation followed by in vitro fertilization (IVF) as a good model to study the relationship between adenomyosis and fertility ${ }^{48}$. However, so far there's no available data concerning the possible impact of adenomyosis on endometrial receptivity in oocytes donation IVF cycles. A study published in 2005 showed how patients with JZ thickness of $10-12 \mathrm{~mm}$ or $>12 \mathrm{~mm}$ have lower pregnancy rates ( $16 \%$ and $5 \%$, respectively) when compared to patients with $\mathrm{JZ}<10 \mathrm{~mm}(45 \%)$, concluding that MRI evaluation of JZ thickness could be considered as the most important negative predicted factor for implantation failure in IVF cycles ${ }^{49}$. A further prospective study conducted by the same group evaluated the influence of JZ thickness on pregnancy outcome in 152 infertile patients with an indication for $\operatorname{IVF}^{50}$. All patients had a pelvic MRI scan before IVF. The obtained results showed that JZ thickness increase is significantly correlated with implantation failure. In fact, patients with a $\mathrm{JZ}$ of 7-10 $\mathrm{mm}$ had an implantation failure rate of $95.8 \%$ compared to the $37.5 \%$ of all other patients $(\mathrm{P}<0.0001)$.

Recently, Thalluri and Tremellen published a retrospective cohort study of 213 patients (38 with ultrasound diagnosed adenomyosis and 175 with no signs of adenomyosis on the scan) who underwent GnRH antagonist stimulation for IVF treatment ${ }^{51}$. All patients were $\leq 39$ years old, had 
good quality Day 4/5 embryo for single-embryo transfer and showed no uterine fibroids, hydrosalpinx or endometrial polyps on the scan. The viable clinical pregnancy rate was $23.6 \%$ in the adenomyosis group and $44.6 \%$ in the non-adenomyosis group $(\mathrm{P}=0.017)$. The decline in viable pregnancy rate in the adenomyosis group remained statistically significant even after the logistic regression analysis performed because median maternal age and duration of infertility were significantly higher in the adenomyosis group (OR 1/4 0.408, CI 1/4 0.181-0.922, P 1/4 0.031 when adjusting for maternal age; OR $1 / 40.417$, CI $1 / 40.175-0.989, \mathrm{P} 1 / 40.047$ when adjusting for duration of infertility). A recent meta-analysis, published in 2014, supports the negative influence of adenomyosis on implantation of good quality embryos in patients undergoing IVF treatment ${ }^{52}$. This analysis included nine studies with a total of 1865 women, 306 of which diagnosed with adenomyosis. The authors find out that women with adenomyosis exert a $28 \%$ reduction in clinical pregnancy when compared to women without adenomyosis. Miscarriage rates are also increased in women with adenomyosis.

\section{TREATMENT OPTIONS AND REPRODUCTIVE OUTCOME}

Several pregnancies were achieved after the treatment of adenomyosis (hormonal therapy, HIFU, conservative surgery, combined therapy) (Table 1).

\section{Medical treatment}

Several medical regimens have been used over the last 20 years in the treatment of adenomyosis associated infertility ${ }^{53}$. The first drugs employed for this purpose were gonadotropin-releasing hormone agonists $(\mathrm{GnRHa})^{54}$. It seems in fact that GnRHa could have specific effects in women with adenomyosis. First of all, they may reduce or suppress the expression of nitric oxide synthases (NOS) in the endometrium and thus reducing the free radicals concentration in the glandular epithelium $^{55}$. They could also decrease the expression of P450 aromatase, that is overexpressed in patients with adenomyosis, enhancing uterine receptivity ${ }^{56}$. Furthermore GnRHa do not significantly affect the decidualization process of endometrial stromal cells and they seem to have no repercussion on human blastocyst invasion ${ }^{57}$.

The first pregnancy obtained after a 6-month treatment with GnRHa was first achieved by Hirata et al. in $1993^{58}$. The patient was 36 years old and had a history of 4 years secondary infertility. She conceived spontaneously shortly after cessation of the treatment, but later experienced a spontaneous abortion at 10 weeks of gestation. The same years Nelson and Corson published a case 
study of a 19 years old patient affected by adenomyosis (histologically diagnosed) that spontaneously conceived after cessation of a 3 months course of $\mathrm{GnRH}-\mathrm{a}^{59}$. Although, this patient had no previous history of infertility. The first live birth after a long term treatment with GnRH-a in a patient affected by adenomyosis associated secondary infertility was reported by Silva and colleagues in $1994^{60}$. Other small studies also reported successful conceptions and deliveries after using GnRHa ${ }^{61-63}$.

\section{High Intensity Focused Ultrasound}

High intensity focused ultrasound (HIFU) or focused ultrasound surgery (FUS) is a non-invasive technique that causes typical coagulation necrosis by focusing high intensity ultrasound on a targeted area. Over the last 10 years it has been widely used for the treatment of gynecological diseases (solid tumors, fibroids) and recently it has received increasing interest in treating adenomyosis $^{64-66}$. Both MRI and US could be used for guidance. MRI offers a better anatomical resolution and, thanks to MRI-based thermal mapping, a real-time temperature monitoring during HIFU. On the other hand US is less expensive, quiet and greyscale change during HIFU offers a real-time anatomical monitoring imaging ${ }^{65}$. Furthermore the patient doesn't need to be enclosed in a confined place. An accurate selection of the patients seems to be utmost important because several elements may influence the ablative efficiency of HIFU. In a recent retrospective study published by Gong et al. 245 patients affected by adenomyosis underwent US guided HIFU and received a MRI before and after the procedure in order to evaluate the efficacy of the treatment ${ }^{67}$. Several factors were found to influence the treatment: abdominal thickness, location and volume of the lesion and its blood supply ${ }^{68-71}$. In the last years few studies have examined the feasibility and the efficacy of HIFU (MRI- or US-guided) in the treatment of diffuse and focal adenomyosis indicating that is safe and that represents a good option for symptomatic adenomyotic lesions ablation ${ }^{64,66,72-74}$.

The first live birth after MRgFUS for focal adenomyosis was reported in $2006^{75}$. Rabinovici et al. published a case report of a 36-years-old patient with a secondary infertility due to a symptomatic focal adenomyosis. The patient underwent MRgFUS with an improvement in menometrorrhagia and with a significant reduction in lesion size. 3 menstrual cycles after she conceived spontaneously with the delivery at term of an healthy baby. So far, the role of HIFU as a treatment option for adenomyosis associated infertility has not yet been sufficiently clarified and there are limited data concerning its potential impact on fertility and pregnancy outcome. Although some general considerations on side-effects could be made. A permanent amenorrhea resulting in early menopause due to an accidental direct sonication of the ovaries could be a serious complication of 
any interventional treatment with HIFU. Indeed, an ultrasonic beam accidentally focused on the ovaries could lead to a permanent loss of the ovarian function ${ }^{76}$. Although, so far there are no studies on endocrine changes or on anti-Müllerian hormone levels alterations after inadvertent ovaries sonication during HIFU treatment for adenomyosis. Concerning the endometrium, it has been reported that its selective sonication is associated with well known morphological abnormalities $^{77}$, but the possibility that accidental sonication of adjacent endometrial tissue could impair the endometrial function and consequently the implantation process has not been demonstrated, yet. Moreover, the change in myometrial architecture after the degeneration of the lesion and the potential presence of post treatment intracavitary adhesions may lead to a further loss of uterine functionality, introducing an additional risk factor for uterine sterility.

\section{Uterus-sparing surgical treatment}

The standard surgical treatment of symptomatic adenomyosis is hysterectomy. However, this is not an option for patients who want to preserve their fertility. A recent review published by Grimbizis et al. shows that conservative surgery for adenomyosis may represent a feasible choice for patients with childbearing desire, even if its impact on fertility outcomes needs further investigation ${ }^{78}$. The selection of good candidate and the choice of the optimal uterus-sparing surgical treatment could be challenging for several reasons, some related to the disease itself. Adenomyosis is often associated to other gynecological conditions (endometriosis, fibroids, polyps) and that could lead to significant bias when analyzing the effect of the treatment. Furthermore, there are no standardized diagnostic criteria. This lack of a common consensus makes difficult to evaluate the treatment outcomes and to compare studies where different criteria are used. Moreover, the adenomyotic foci often deeply invade the myometrium making the complete resection of the lesions almost impossible and the removal of healthy myometrial tissue almost inevitable. Indeed the uterine cavity is often entered during surgery ${ }^{79}$ and it is difficult to repair ${ }^{80}$. An inadequate surgical reconstruction, complicated by an incomplete removal of adenomyotic foci could lead to a poor healing of the scar, decreasing the tensile strength of the uterus and increasing the risk of uterine rupture during pregnancy or labor ${ }^{81}$.

\section{$\underline{\text { Adenomyoma excision }}$}

Adenomyomectomy (open or laparoscopic) is an approach that is preferably used in case of focal type adenomyosis. In fact, the complete excision is possible only if the lesions are clearly defined. The technique includes the following steps $^{78}: 1$ ) recognition of lesions' location and borders by inspection/palpation (under ultrasound guidance if necessary), 2) longitudinal excision along the adenomyotic lesion, 3) delicate dissection of the adenomyoma, 4) closure of the uterine cavity (if 
needed) with absorbable suture, 5) suture the uterine wall layer by layer (no dead space should be left). The risk of entering the uterine cavity or of destroying unaffected myometrium with this technique is really low.

\section{Cystectomy}

Cystic adenomyosis is a rare form of focal adenomyosis, more commonly encountered in young patients. Large hemorrhage within ectopic cystic glands results in fact in the appearance of a circumscribed lesion. Considered the rarity of these lesions and their closeness to the ovaries, they are often considered endometriotic cysts. A recent review of the literature underlines how this type of lesions have been described and classified with several terms, leading to considerable confusion $^{82}$. The authors propose a new classification based on the lining epithelium and recommend an accurate description of the lesions that allows adequate comparison. The one proposed follows the acronym MUSCLE (Myometrial location, Uterine site, Structure, Contents, Level, Endometrial or inner lining). Given the fact that most of the patients affected are young, a minimally invasive approach is preferable. During laparoscopy the affected tissue appears paler and less vascular. During suturing no dead space should be left and if the endometrial cavity is entered it should be repaired separately. Furthermore, an accurate reconstruction of the uterus is mandatory in order to preserve fertility and to reduce the risk of uterine rupture in case of pregnancy.

\section{Myometrial reduction}

Myometrial reduction (or conservative cytoreductive uterine-sparing surgery) is a more complicated technique that is performed in case of diffuse adenomyosis. Different approaches, both laparotomic and laparoscopic, have been described. In any of them the purpose is to remove as much of adenomyotic tissue as possible with a subsequent metroplasty. The classical method starts with a midline incision (transversal or longitudinal) on the anterior or posterior uterine wall followed by the resection "piece by piece" of all clinically recognizable abnormal tissue ${ }^{83}$. In 2004 Fujishita et al. proposed the transverse $\mathrm{H}$ incision technique, a laparotomic approach, mainly performed in case of anterior adenomyosis. The main steps are: 1) a vertical incision followed by two other perpendicular incisions along the superior and inferior edges of the uterus (H-shaped); 2) a $5 \mathrm{~mm}$ thick resection of the uterine serosa from the myometrium along the vertical incision; 3) serial excisions of "slices" of adenomyotic tissue, using manual palpation to identify the normal myometrium; 4) multiple chromoperturbation tests with indigo carmine solution to reduce the risk 
of uterine cavity penetration; 5) endometrial and myometrial closure by layers. In their study the authors also compared the two techniques in 11 patients, where 5 underwent the classical reduction (classical group) and 6 the modified $\mathrm{H}$ incision method (modified group). Results showed no difference in operation time, blood loss and size of removed specimens, with a greater pain relief and a spontaneous pregnancy in the modified group ${ }^{84}$. In 2010 Nishida et al. proposed a third surgical approach: the asymmetric dissection of the uterus ${ }^{85}$. This laparotomic technique allows to preserve both the uterine cavity and the uterine arteries. The uterus is dissected longitudinally using a high-frequency electric surgical knife in an asymmetrical fashion to divide inside and outside. From this incision, the myometrium is dissected diagonally, as if hollowing out the uterine cavity. Next the uterine cavity is opened by a transversal incision, the index finger is inserted into the uterine cavity and the adenomyotic tissue is removed by using a loop electrode. Then the uterine cavity is closed using a 3-0 absorbable suture and the uterine flaps rejoined in layers. This technique was performed in 44 patients with diffuse adenomyosis and menstruation resumed in all patients 3 months after the surgery. A significant improvement in dysmenorrhea and anemia due to menorrhagia is reported. Furthermore 2 patients became pregnant after the procedure (1 spontaneous interstitial pregnancy and 1 normal pregnancy after IVF/ET still continuing during the time of publication). Myometrial reduction may represent a good option for patients with childbearing desire. Although this type of surgery results in a reduce volume uterus and causes uterine scars, burdening future pregnancies. Indeed, the reduced myometrial surface may predispose to spontaneous abortion and premature labor and the uterine scaring may weaken the uterine walls increasing the risk of uterine rupture ${ }^{85-87}$

\section{Fertility Outcome}

Data regarding the impact of uterine-sparing surgery on fertility potential are controversial, also because most of the published studies weren't designed to address this issue. Uterus-sparing surgery includes different techniques that change the anatomy of the uterus itself. Intrauterine and pelvic adherences and uterine deformation as well as a decreased uterine capacity are possible complications and could be responsible for a reduced postoperative pregnancy rate ${ }^{85}$. However, in the paper published by Grimbizis et al. pregnancy rates were reported to be $46.9 \%$ in women treated with cytoreductive surgery and $60.5 \%$ in women who underwent adenomyomectomy ${ }^{78}$. Other studies support the beneficial effect of uterus-sparing surgery on fertility potential; patients with localized adenomyosis after myomectomy had a high pregnancy rate (from $48,2 \%$ to $77,5 \%$ ) with a successful delivery rate that ranges from $26.8 \%$ to $69 \%$. Furthermore, in a recent study published in 2014, 102 women who underwent laparoscopic adenomyomectomy were evaluated ${ }^{90}$. 
The total clinical pregnancy rate (spontaneous and after IVF) was 31.4\%. In addition, the authors analyzed pregnancy rates considering the age of the patient. Better results were found in the group < 39 years old $(41.3 \%)$ when compared to patients $>40$ years old $(3.7 \%)$ concluding that surgery represents a feasible option for patients affected by adenomyosis especially at ages $<39$ years. Even though conservative surgery might not have a comparable effect on reproductive performance in patients with diffuse-type adenomyosis, some studies report a pregnancy rate of $>30-40 \%$ in women with diffuse adenomyosis after surgery ${ }^{89,91,92}$. In addition, spontaneous pregnancy might occur 36 months after complete conservative surgery, compared with the 6 months of subfertile women with adenomyosis treated with GnRH agonist, advising that the therapeutic effect of conservative surgery could last longer than medical treatment ${ }^{93}$.

\section{Combination therapy}

The combination of uterine-sparing surgery and medical therapy (i.g. GnRH agonists) in managing adenomyosis-related symptoms is still controversial. A prolonged treatment with GnRH agonists causes a deep suppression of gonadotropin secretion, suppressing the ovarian function and consequently leading to a profound hypo-estrogenism. Since GnRH receptors have been found in endometrial and adenomyotic tissue, they could have a direct anti-proliferative action, reducing uterine vascularity ${ }^{94}$. Possible advantages of a preoperative treatment with GnRH agonists comprehend a reduced bleeding during surgery and the possible amelioration of a frequent preoperative anemia. On the other hand, the differentiation between normal and adenomyotic tissue could become more difficult, increasing the risk of endometrial perforation and incomplete removal of the lesions ${ }^{84}$. Concerning the postoperative administration of GnRH agonists, a prospective study published in 2009, evaluated 165 patients. All patients underwent a uterus-sparing surgery for adenomyosis (minilaparotomy, ultraminilaparotomy or laparoscopy) and 114 of them received a six-course treatment with GnRH agonist regimen postoperatively. Both groups showed a significant symptom improvement (dysmenorrhea, menorrhagia) during the 2 years follow up with lower symptom recurrence in the surgical-medical group ${ }^{89}$. On the other hand, in a recent study published by Chong et al, no significant difference was found in terms of long-term symptom control after laparoscopic/robotic adenomyomectomy with or without GnRH agonist treatment ${ }^{95}$. Concerning the reproductive outcomes, Wang et al. found no difference in terms of clinical pregnancy and successful delivery in patients treated with conservative surgery alone and patients who underwent a postoperative GnRH agonist treatment ${ }^{89}$.

The first live birth after combined therapy was first reported in $1999^{96}$. A year later Wang et al. also 
reported 3 successful pregnancies ${ }^{97}$. In a large prospective study published in 2009, 114 patients underwent conservative surgery followed by a 6-course GnRHa treatment and 32 of them had successful deliveries ${ }^{89}$.

\section{Perinatal complications of the pregnancy}

The potential consequences of adenomyosis during pregnancy are difficult to evaluate because, at the present time, there are few data available concerning adenomyosis and major obstetrical complications. Early miscarriage, preterm delivery, abnormal placentation, intrauterine growth restriction and spontaneous uterine rupture are possible adenomyosis-related complications recorded in the literature.

A recent study conducted by Mochimaru and colleagues compared pregnancy outcomes between patients diagnosed with adenomyosis before pregnancy and a control group ${ }^{98}$. The adenomyosis group showed higher rates of preterm premature rupture of membranes (19.4\% vs $4.2 \%)$, preterm delivery (41.7\% vs $12.5 \%)$ and small-for-gestational age (33.3\% vs $10.4 \%)$.

The risk of uterine rupture after uterine surgery is well known: reports of vaginal birth after caesarean delivery (VBAC) or laparoscopic myomectomy reported a $0.27 \%$ and $1.0 \%$ incidence, respectively ${ }^{99,100}$. The risk of uterine rupture after conservative surgery for adenomyosis is also well established $^{101}$. In case of adenomyosis the connective tissue matrix that separates the myocites contains less elastic collagen fibrils, diminishing the elasticity of the tissues. Furthermore, the uterine scars may also contain adenomyotic remnants that could lead to a reduced tensile strength and increase the risk of rupture 30,102 .

A recent study published in 2016 investigates the correlation between uterine wall thickness after uterine-sparing surgery and pregnancy outcome ${ }^{103} .23$ healthy women, who become pregnant after a laparotomic surgical procedure for symptomatic adenomyosis, were evaluated. For this uterinesparing surgery, in all cases, the uterus was dissected asymmetrically in a longitudinal manner. A measure of minimum and maximum uterine wall thickness (from the serosa to the uterine endometrium) was then performed (MRI and/or sonography) in the time interval between surgery and conception. Of all patients, $54.5 \%$ proceeded to delivery, $34.8 \%$ had a miscarriage and $8.7 \%$ had a uterine rupture and fetal loss before 20 weeks of gestation, where a strong correlation between uterine wall thickness $<7 \mathrm{~mm}$ was found. The authors also found that patients with a minimum uterine wall thickness $>15 \mathrm{~mm}$ were more likely to have a miscarriage, even if no significant 
difference was shown. The cases of uterine rupture were likely related to the invasion of the placenta into the myometrial layer with residual adenomyotic foci. Altered placentation (e.g. placenta accreta/increta/percreta) could be another possible perinatal complication of uterinesparing surgery because of the risk of small perforation of the endometrium during surgery. Indeed, a defect on the subendometrial myometrium could promote the invasion of the placenta into the outer myometrium $^{90}$. Few reports have also pointed out the risk of a severe post-partum hemorrhage non-responding to conservative treatment, in which a peripartum hysterectomy was required ${ }^{104,105}$. Given the absence of systematic data and the lack of experience, an elective caesarean section after uterine-sparing surgery seems to be the best option so far.

\section{Conclusions}

Adenomyosis represents a common gynecological disorder with a negative impact on fertility. However, it remains challenging to establish if adenomyosis is the only cause of the infertility or not, because patients, in both case and control groups, may be affected by concomitant endometriosis. Furthermore, at the present time, limited data are available concerning the efficacy of the different treatment options of adenomyosis on fertility outcome and the only ones published are retrospective evaluations or small case series. Further studies are required to determine the reason of implantation failure in women with adenomyosis and the impact of adenomyosis on infertile women with or without endometriosis. 


\section{References}

1. Brosens JJ, Barker FG, De Souza NM. Myometrial zonal differentiation and uterine junctional zone hyperplasia in the nonpregnant uterus. Hum Reprod Update 1998;4:496-502

2. Ascher-Walsh $\mathrm{CJ}, \mathrm{Tu} J \mathrm{~J}, \mathrm{Du} \mathrm{Y}$ et al. Location of adenomyosis in total hysterectomy specimens. J Am Assoc Gynecol Laparosc. 2003;10:360-2

3. Bergholt T, Eriksen L, Ferendt $\mathrm{N}$ et al. Prevalence and risk factors of adenomyosis at hysterectomy. Hum Reprod 2001;16: 2418-21

4. Farquhar C, Brosens I. Medical and surgical management of adenomyosis. Best Pract Res Clin Obstet Gynaecol 2006;20:603-16

5. Uduwela A, Perra M, Aiquig L, et al. Endometrial-myometrial interface: relationship to adenomyosis and changes in pregnancy. Obstet Gynecol Surv 2000;55:390-400

6. Ferenczy A. Pathophysiology of adenomyosis. Hum Reprod Update 1998;4:312-22

7. Bergeron C, Amant F, Ferency A. Pathology and physiology of adeno myosis. Best Pract Res Clin Obstet Gynaecol 2006;20:511-21

8. Azziz R. Adenomyosis: current perspectives. Obstet Gynecol Clin North Am 1989;16:22135

9. Dueholm M. Transvaginal ultrasound for diagnosis of adenomyosis: a review. Best Pract Res Clin Obstet Gynaecol 2006;20:569-82

10. Bazot M, Cortez A, Darai E, et al. Ultrasonography compared with magnetic resonance imaging for the diagnosis of adenomyosis: correlation with histopathology. Hum Reprod 2001;16:2427-33

11. Van den Bosch T, Dueholm M, Leone FP, et al. Terms, definitions and measurements to describe sonographic features of myometrium and uterine masses: a consensus opinion from the Morphological Uterus Sonographic Assessment (MUSA) group. Ultrasound Obstet Gynecol 2015;46:284-98

12. Di Donato N, Bertoldo V, Montanari G, et al. Question mark form of uterus: a simple sonographic sign associated to the presence of adenomyosis. Ultrasound Obstet Gynecol 2015;46:126-7

13. Exacoustos C, Brienza L, Di Giovanni A, et al. Adenomyosis: three-dimensional sonographic findings of the junctional zone and correlation with histology. Ultrasound Obstet Gynecol 2011;37:471-9

14. Van den Bosch T, Votino A, Cornelis A, et al. Optimizing the Histological Diagnosis of Adenomyosis Using in vitro Three-Dimensional Ultrasonography. Gynecol Obstet Invest 2016;81:563-7 
15. Sharma K, Bora MK, Venkatesh BP, et al. Role of 3D Ultrasound and Doppler in Differentiating Clinically Suspected Cases of Leiomyoma and Adenomyosis of Uterus. J Clin Diagn Res 2015;9:QC08-12

16. Exacoustos C, Manganaro L, Zupi E. Imaging for the evaluation of endometriosis and adenomyosis. Best Pract Res Clin Obstet Gynaecol 2014;28:655-81

17. Larsen SB, Lundorf E, Forman A, et al. Adenomyosis and junctional zone changes in patients with endometriosis. Eur J Obstet Gynecol Reprod Biol 2011;157:206-11.

18. Kunz G, Beil D, Huppert P, et al. Adenomyosis in endometriosis-prevalence and impact on fertility. Evidence from magnetic resonance imaging. Hum Reprod 2005;20:2309-16

19. Templeman C, Marshall SF, Ursin G, et al. Adenomyosis and endometriosis in the California Teachers Study. Fertil Steril 2008;90:415-24

20. Benagiano G, Brosens I, Habiba M. Structural and molecular features of the endomyometrium in endometriosis and adenomyosis. Hum Reprod Update 2014;20:386402

21. Vercellini P, Consonni D, Dridi D, et al. Uterine adenomyosis and in vitro fertilization outcome: a systematic review and meta-analysis. Hum Reprod 2014;29:964-77

22. Devlieger R, D'Hooghe T, Timmerman D. Uterine adenomyosis in the infertility clinic. Hum Reprod Update 2003:9;139-47

23. Harada T, Khine YM, Kaponis A, et al. The Impact of Adenomyosis on Women's Fertility. Obstet Gynecol Surv 2016:71,557-68

24. Matalliotakis IM, Katsikis IK, Panidis DK. Adenomyosis: what is the impact on fertility? Curr Opin Obstet Gynecol 2005;17:261-4

25. Campo S, Campo V, Benagiano G. Adenomyosis and infertility. Reprod Biomed Online 2012;24:35-46

26. Farhi J, Ashkenazi J, Feldberg D, et al. Effect of uterine leiomyomata on the results of invitro fertilization treatment. Hum Reprod 1995;10:2576-8

27. Stovall DW, Parrish SB, Van Voorhis BJ, et al. Uterine leiomyomas reduce the efficacy of assisted reproduction cycles: results of a matched follow-up study. Hum Reprod 1998;13:192-7

28. Kunz G, Leyendecker G. Uterine peristaltic activity during the menstrual cycle: characterization, regulation, function and dysfunction. Reprod Biomed Online 2002;4:5-9

29. Kissler S, Hamscho N, Zangos S, et al. Uterotubal transport disorder in adenomyosis and endometriosis--a cause for infertility. BJOG 2006;113:902-8

30. Mehasseb MK, Bell SC, Pringle JH, et al. Uterine adenomyosis is associated with 
ultrastructural features of altered contractility in the inner myometrium. Fertil Steril 2010;93:2130-6

31. Quinn M. Uterine innervation in adenomyosis. J Obstet Gynaecol 2007;27:287-91

32. Ota $\mathrm{H}$, Tanaka T. Stromal vascularization in the endometrium during adenomyosis. Microsc Res Tech 2003;60:445-9

33. $\mathrm{Li} \mathrm{T}, \mathrm{Li}$ YG, Pu DM. Matrix metalloproteinase-2 and -9 expression correlated with angiogenesis in human adenomyosis. Gynecol Obstet Invest 2006;62:229-35

34. Goteri G, Lucarini G, Montik N, et al. Expression of vascular endothelial growth factor (VEGF), hypoxia inducible factor-1alpha (HIF-1alpha), and microvessel density in endometrial tissue in women with adenomyosis. Int J Gynecol Pathol 2009;28:157-63

35. Ulukus M, Ulukus EC, Seval Y, et al. Expression of interleukin-8 receptors in patients with adenomyosis. Fertil Steril 2006;85:714-20

36. Wang F, Li H, Yang Z, et al. Expression of interleukin-10 in patients with adenomyosis. Fertil Steril 2009;91:1681-5

37. Fischer CP, Kayisili U, Taylor HS. HOXA10 expression is decreased in endometrium of women with adenomyosis. Fertil Steril 2011;95:1133-6

38. Mikolajczyk M, Wirstlein P, Skrzypczak J. Leukaemia inhibitory factor and interleukin 11 levels in uterine flushings of infertile patients with endometriosis. Hum Reprod 2006;21:3054-8

39. Xiao $Y$, Sun $X$, Yang $X$, et al. Leukemia inhibitory factor is dysregulated in the endometrium and uterine flushing fluid of patients with adenomyosis during implantation window. Fertil Steril 2010;94:85-9

40. Wicherek L. Alterations in RCAS1 serum concentration levels during menstrual cycle in patients with uterine leiomyoma and lack of analogical changes in adenomyosis. Gynecol Obstet Invest 2009;67:195-201

41. Mehasseb MK, Panchal R, Taylor AH, et al. Estrogen and progesterone receptor isoform distribution through the menstrual cycle in uteri with and without adenomyosis. Fertil Steril 2011;95:2228-35

42. Telfer JF, Irvine GA, Kohnen G, et al. Expression of endothelial and inducible nitric oxide synthase in non-pregnant and decidualized human endometrium. Mol Hum Reprod 1997;3:69-75

43. Ota H, Igarashi S, Hatazawa J, et al. 1999. Immunohistochemical assessment of superoxide dismutase expression in the endometrium in endometriosis and adenomyosis. Fertil Steril 1999;72:129-34 
44. Ota H, Igarashi S, Hatazawa J, et al. Is adenomyosis an immune disease? Hum Reprod Update 1998;194:360-7

45. Yen CF, Huang SJ, Lee CL, et al. Molecular Characteristics of the Endometrium in Uterine Adenomyosis and Its Biochemical Microenvironment. Reprod Sci 2017 Epub ahead of print doi: $10.1177 / 1933719117691141$

46. Garavaglia E, Audrey S, Annalisa I, et al. Adenomyosis and its impact on women fertility. Iran J Reprod Med 2015;13:327-36

47. Barrier BF, Malinowski MJ, Dick EJ Jr, et al. Adenomyosis in the baboon is associated with primary infertility. Fertil Steril 2004;82:1091-4

48. Soares SR, Velasco JA, Fernandez M, et al. Clinical factors affecting endometrial receptiveness in oocyte donation cycles. Fertil Steril 2008;89:491-501

49. Piver P. Uterine factors limiting ART coverage. J Gynecol Obstet Biol Reprod (Paris) 2005;34:5S30-3

50. Maubon A, Faury A, Kapella M, et al. Uterine junctional zone at magnetic resonance imaging: a predictor of in vitro fertilization implantation failure. J Obstet Gynaecol Res 2010;36:611-8

51. Thalluri V, Tremellen KP. Ultrasound diagnosed adenomyosis has a negative impact on successful implantation following GnRH antagonist IVF treatment. Hum Reprod 2012;27:3487-92

52. Vercellini P, Consonni D, Barbara G, et al. Adenomyosis and reproductive performance after surgery for rectovaginal and colorectal endometriosis: a systematic review and metaanalysis. Reprod Biomed Online 2014;28:704-13

53. Fedele L, Bianchi S, Frontino G. Hormonal treatments for adenomyosis. Best Pract Res Clin Obstet Gynaecol 2008;22:333-9

54. Grow DR, Filer RB. Treatment of adenomyosis with long-term GnRH analogues: a case report. Obstet Gynecol 1991;78:538-9

55. Kamada Y, Nakatsuka M, Asagiri K, et al. GnRH agonist-suppressed expression of nitric oxide synthases and generation of peroxynitrite in adenomyosis. Hum Reprod 2000;15:2512-9

56. Ishihara H, Kitawaki J, Kado N, et al. Gonadotropin-releasing hormone agonist and danazol normalize aromatase cytochrome P450 expression in eutopic endometrium from women with endometriosis, adenomyosis, or leiomyomas. Fertil Steril 2003;79:735-42

57. Klemmt PA, Liu F, Carver JG, et al. Effects of gonadotrophin releasing hormone analogues on human endometrial stromal cells and embryo invasion in vitro. Hum Reprod 
$2009 ; 24: 2187-92$

58. Hirata JD, Moghissi KS, Ginsburg KA. Pregnancy after medical therapy of adenomyosis with a gonadotropin-releasing hormone agonist. Fertil Steril 1993;59:444-5

59. Nelson JR, Corson SL. Long-term management of adenomyosis with a gonadotropinreleasing hormone agonist: a case report. Fertil Steril 1993;59:441-3

60. Silva PD, Perkins HE, Schauberger CW. Live birth after treatment of severe adenomyosis with a gonadotropin-releasing hormone agonist. Fertil Steril 1994;61:171-2

61. Huang FJ, Kung FT, Chang SY, et al. Effects of short-course buserelin therapy on adenomyosis. A report of two cases. J Reprod Med 1999; 44:741-4

62. Igarashi M, Abe $\mathrm{Y}$, Fukuda $\mathrm{M}$, et al. Novel conservative medical therapy fôr uterine adenomyosis with a danazol-loaded intrauterine device. Fertil Steril 2000;74:412-3

63. Shawki O, Igarashi M. Danazol loaded intrauterine device (IUD) for management of uterine adenomyosis: a novel approach. Fertil Steril 2002;77:S24

64. Fukunishi H, Funaki K, Sawada K, et al. Early result of magnetic resonance-guided focused ultrasound surgery of adenomyosis: analysis of 20 cases. J Minim Invasive Gynecol 2008;15:571-9

65. Orsi F, Arnone P, Chen W, et al. High intensity focused ultrasound ablation: a new therapeutic option for solid tumors. J Cancer Res Ther 2010;6:414-20

66. Zhou M, Chen JY, Tang LD, et al. Ultrasound-guided high-intensity focused ultrasound ablation for adenomyosis: the clinical experience of a single center. Fertil Steril 2011;95:900-5

67. Gong C, Yang B, Shi Y, et al. Factors influencing the ablative efficiency of high intensity focused ultrasound (HIFU) treatment for adenomyosis: A retrospective study. Int J Hyperthermia 2016;32:496-503

68. Chen L, ter Haar G, Hill CR. 1997. Influence of ablated tissue on the formation of highintensity focused ultrasound lesions. Ultrasound Med Biol 1997;23:921-31

69. Baker KG, Robertson VJ, Duck FA. A review of therapeutic ultrasound: biophysical effects. Phys Ther 2001;81:1351-8

70. Funaki K, Fukunishi H, Funaki T, et al. Magnetic resonance-guided focused ultrasound surgery for uterine fibroids: relationship between the therapeutic effects and signal intensity of preexisting T2-weighted magnetic resonance images. Am J Obstet Gynecol 2007;196:184

71. Zhang X, Li K, Xie B, et al. Effective ablation therapy of adenomyosis with ultrasoundguided high-intensity focused ultrasound. Int J Gynaecol Obstet 2014;124:207-11

72. Fan TY, Zhang L, Chen W, et al. Feasibility of MRI-guided high intensity focused 
ultrasound treatment for adenomyosis. Eur J Radiol 2012;81:3624-30

73. Wang W, Wang Y, Tang J. 2009. Safety and efficacy of high intensity focused ultrasound ablation therapy for adenomyosis. Acad Radiol 2009;16:1416-23

74. Zhang L, Zhang W, Orsi F, et al. 2015. Ultrasound-guided high intensity focused ultrasound for the treatment of gynaecological diseases: a review of safety and efficacy. Int $\mathrm{J}$ Hyperthermia 2015;31:280-4

75. Rabinovici J, Inbar Y, Eylon SC, et al. Pregnancy and live birth after focused ultrasound surgery for symptomatic focal adenomyosis: A case report. Hum Reprod 2006;21:1255-9.

76. Wang SW, He XY, Li MZ. High-intensity focused ultrasound compared with irradiation for ovarian castration in premenopausal females with hormone receptor-positive breasst cancer after radical mastectomy. Oncol Lett 2012;4:1087-109

77. Fruehauf JH, Back W, Eiermann A, et al. High-intensity focused ultra- sound for the targeted destruction of uterine tissues: experiences from a pilot study using a mobile HIFU unit. Arch Gynecol Obstet 2008;277:143-50

78. Grimbizis GF, Mikos T, Tarlatzis B. Uterus-sparing operative treatment for adenomyosis. Fertil Steril 2014;101:472-87

79. Wang PH, Fuh JL, Chao HT, et al. Is the surgical approach beneficial to subfertile women with symptomatic extensive adenomyosis? J Obstet Gynaecol Res 2009:3;495-502

80. Yen MS, Yang TS, Yu KJ, et al. Comments on laparoscopic excision of myometrial adenomyomas in patients with adenomyosis uteri and main symptoms of severe dysmenorrhea and hypermenorrhea. J Am Assoc Gynecol Laparosc 2004;11: 441

81. Sun HD, Su WH, Chang WH, et al. Rupture of a pregnant unscarred uterus in an early secondary trimester: a case report and brief review. J Obstet Gynaecol Res 2012;38:442-5

82. Brosens I, Gordts S, Habiba M, et al. Uterine Cystic Adenomyosis: A Disease of Younger Women. J Pediatr Adolesc Gynecol 2015;28:420-6

83. Garcia L, Isaacson K. Adenomyosis: review of the literature. J Minim Invasive Gynecol $2011 ; 18: 428-37$

84. Fujishita A, Masuzaki H, Khan KN, et al. Modified reduction surgery for adenomyosis. A preliminary report of the transverse $\mathrm{H}$ incision technique. Gynecol Obstet Invest $2004 ; 57: 132-8$

85. Nishida M, Takano K, Arai Y, et al. Conservative surgical management for diffuse uterine adenomyosis. Fertil Steril 2010;94:715-9

86. Pepas L, Deguara C, Davis C. Update on the surgical management of adenomyosis. Curr Opin Obstet Gynecol 2012;24:259-64 
87. Wood C. Surgical and medical treatment of adenomyosis. Hum Reprod Update 1998;4:32336

88. Chang WH, Wang KC, Lee NR, et al. Reproductive performance of severely symptomatic women with uterine adenomyoma who wanted preservation of the uterus and underwent combined surgical-medical treatment. Taiwan J Obstet Gynecol 2013;52:39-45

89. Wang PH, Liu WM, Fuh JL, et al. Comparison of surgery alone and combined surgicalmedical treatment in the management of symptomatic uterine adenomyoma. Fertil Steril 2009;92:876-85

90. Kishi Y, Yabuta M, Taniguchi F. Who will benefit from uterus-sparing surgery in adenomyosis associated subfertility? Fertil Steril 2014;102:802-7

91. Huang BS, Seow KM, Tsui KH, et al. Fertility outcome of infertile women with adenomyosis treated with the combination of a conservative microsurgical technique and GnRH agonist: long-term follow-up in a series of nine patients. Taiwan J Obstet Gynecol 2012;51:212-6

92. Wang PH, Yang TS, Lee WL, et al. Treatment of infertile women with adenomyosis with a conservative microsurgical technique and a gonadotropin-releasing hormone agonist. Fertil Steril 2000;73:1061-2

93. Tsui KH, Lee FK, Seow KM, et al. Conservative surgical treatment of adenomyosis to improve fertility: Controversial values, indications, complications, and pregnancy outcomes. Taiwan J Obstet Gynecol 2015;54:635-40

94. Khan KN, Kitajima M, Hitachi K, et al. Changes in tissue inflammation, angiogenesis and apoptosis in endometriosis, adenomyosis and uterine myoma after GnRH agonist therapy. Hum Reprod 2010;25:642-53

95. Chong GO, Lee YH, Hong DG, et al. Long-Term Efficacy of Laparoscopic or Robotic Adenomyomectomy with or without Medical Treatment for Severely Symptomatic Adenomyosis. Gynecol Obstet Invest 2016;81:346-52

96. Ozaki T, Takahashi K, Okada M, et al. Live birth after conservative surgery for severe adenomyosis following magnetic resonance imaging and gonadotropin-releasing hormone agonist therapy. Int J Fertil Womens Med 1999;44:260-4

97. Wang PH, Yang TS, Lee WL, et al. Treatment of infertile women with adenomyosis with a conservative microsurgical technique and a gonadotropin-releasing hormone agonist. Fertil Steril 2000;73:1061-2

98. Mochimaru A, Aoki S, Oba MS, et al. Adverse pregnancy outcomes associated with adenomyosis with uterine enlargement. J Obstet Gynaecol Res 2015;41:529-33 
99. Dubuisson JB, Fauconnier A, Deffarges JV, et al. Pregnancy outcome and deliveries following laparoscopic myomectomy. Hum Reprod 2000;15:869-73

100. Guise JM, McDonagh MS, Osterweil P, et al. Systematic review of the incidence and consequences of uterine rupture in women with previous caesarean section. BMJ 2004;329:19-25

101. Wada S, Kudo M, Minakami H. Spontaneous uterine rupture of a twin pregnancy after a laparoscopic adenomyomectomy: a case report. J Minim Invasive Gynecol 2006;13:166-8

102. Levgur M. Therapeutic options for adenomyosis: a review. Arch Gynecol Obstet $2007 ; 276: 1-15$

103. Otsubo Y, Nishida M, Arai Y, et al. Association of uterine wall thickness with pregnancy outcome following uterine-sparing surgery for diffuse uterine adenomyosis. Aust $\mathrm{N} \mathrm{Z} \mathrm{J}$ Obstet Gynaecol 2016;56:88-91

104. Coghlin DG. Pregnancy with uterine adenomyoma. Can Med Assoc J 1947;56:315-6

105. Wang PH, Pang YP, Chao HT, et al. Delayed postpartum hemorrhage in adenomyosis: a case report. Zhonghua Yi Xue Za Zhi (Taipei) 1998;61:492-5

106. Strizhakov AN, Davydov AI. Myometrectomy--a method of choice for the therapy of adenomyosis patients in the reproductive period. Akush Ginekol (Mosk). 1995;5:31-3

107. Wang CJ, Yuen LT, Chang SD, et al. Use of laparoscopic cyto-reductive surgery to treat infertile women with localized adenomyosis. Fertil Steril 2006;86:462

108. Takeuchi H, Kitade M, Kikuchi I, et al. Laparoscopic adenomyomectomy and hysteroplasty: a novel method. J Minim Invasive Gynecol 2006;13:150-4

109. Landi S, Mereu L, Pontrelli G, et al. The influence of adenomyosis in patients laparoscopically treated for deep endometriosis. J Minim Invasive Gynecol 2008;15:566-70

110. Al Jama FE. Management of adenomyosis in subfertile women and pregnancy outcome. Oman Med J 2011;26:178-81

111. Osada H, Silber S, Kakinuma T, et al. Surgical procedure to conserve the uterus for future pregnancy in patients suffering from massive adenomyosis. Reprod Biomed Online 2011;22:94-9

112. Saremi A, Bahrami H, Salehian P, et al. Treatment of adenomyomectomy in women with severe uterine adenomyosis using a novel technique. Reprod Biomed Online 2014;28:75360 


\section{Figures and Tables}

Figure 1. Anatomical distortion of the uterine cavity caused by the presence of adenomyosis especially on the posterior wall of the uterus.

Table 1. Reproductive outcome after treatment of adenomyosis 


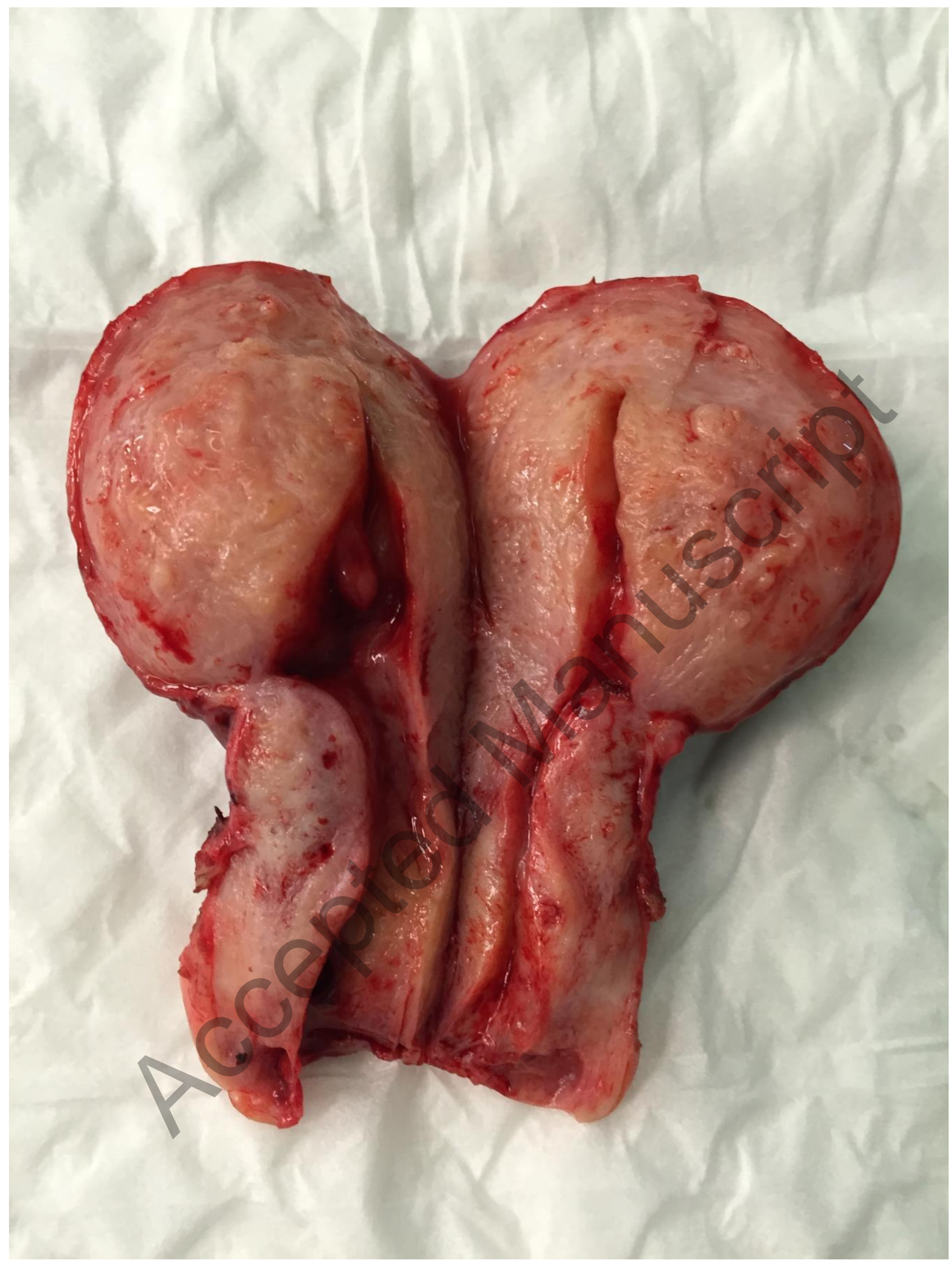




\begin{tabular}{|c|c|c|c|c|c|c|c|}
\hline Reference & $\begin{array}{l}\text { Type of } \\
\text { treatment }\end{array}$ & $\begin{array}{l}\text { Treated } \\
\text { patients } \\
\text { (n) }\end{array}$ & $\begin{array}{l}\text { Age } \\
(y)\end{array}$ & $\begin{array}{l}\text { Infertility } \\
\text { duration }\end{array}$ & $\begin{array}{c}\text { Interval } \\
\text { time }\end{array}$ & $\begin{array}{c}\text { ART/ } \\
\text { Spontaneous } \\
\text { conception }\end{array}$ & $\begin{array}{l}\text { Pregnancy } \\
\text { Outcome }\end{array}$ \\
\hline $\begin{array}{l}\text { Nelson and } \\
\text { Corson }^{59}\end{array}$ & $\begin{array}{l}\text { GnRHa (over } \\
3 \text { years) }\end{array}$ & 1 & 19 & No infertility & 1 month & spontaneous & $\begin{array}{l}\text { Viable first- } \\
\text { trimester } \\
\text { pregnancy }\end{array}$ \\
\hline Hirata et al. ${ }^{58}$ & $\begin{array}{l}\text { GnRHa (6 } \\
\text { months) }\end{array}$ & 1 & 37 & $\begin{array}{l}4 \text { years, } \\
\text { secondary } \\
\text { infertility }\end{array}$ & 4 months & spontaneous & $\begin{array}{l}1 \text { spontaneous } \\
\text { abortion at } \\
10 \mathrm{w}\end{array}$ \\
\hline Silva et al. ${ }^{60}$ & $\begin{array}{l}\text { GnRHa (5 } \\
\text { months) }\end{array}$ & 1 & 36 & $\begin{array}{l}10 \text { years, } \\
\text { secondary } \\
\text { infertility }\end{array}$ & 5 months & spontaneous & $\begin{array}{l}\text { Cesarean } \\
\text { section at term }\end{array}$ \\
\hline $\begin{array}{l}\text { Strizhakov and } \\
\text { Davydov }^{106}\end{array}$ & $\begin{array}{l}\text { Combined } \\
\text { therapy }\end{array}$ & 8 & 18 to 34 & - & $\begin{array}{l}<12 \\
\text { months }\end{array}$ & spontaneous & $\begin{array}{l}4 \text { clinical } \\
\text { pregnancies }\end{array}$ \\
\hline Huang et al. ${ }^{61}$ & $\begin{array}{l}\text { GnRHa (3 } \\
\text { months) }\end{array}$ & 2 & $28-34$ & $\begin{array}{l}2 \text { years and } 4 \\
\text { years }\end{array}$ & $\begin{array}{l}4 \text { to } 6 \\
\text { months }\end{array}$ & leous & $\begin{array}{l}\text { Term, healthy } \\
\text { infant, vaginal } \\
\text { and cesarean } \\
\text { section }\end{array}$ \\
\hline Ozaki et al. ${ }^{96}$ & $\begin{array}{l}\text { Combined } \\
\text { therapy } \\
\text { (danazol) }\end{array}$ & 1 & 33 & $\begin{array}{l}5 \text { years } \\
\text { secondary } \\
\text { infertility }\end{array}$ & $\sim 3$ months & spontaneous & $\begin{array}{l}\text { Cesarean } \\
\text { section at term }\end{array}$ \\
\hline Wang et al. ${ }^{92}$ & $\begin{array}{l}\text { Combined } \\
\text { therapy } \\
(\mathrm{GnRHa}) \\
\end{array}$ & 3 & $\begin{array}{l}32-36- \\
37\end{array}$ & 5 years & $\begin{array}{l}3-12 \\
\text { months }\end{array}$ & - & $\begin{array}{l}\text { Delivered } \\
\text { viable infants }\end{array}$ \\
\hline${ }_{62}^{\text {Igarashi et al. }}$ & Danazol IUD & 4 & - & & & spontaneous & $\begin{array}{l}3 \text { successful } \\
\text { deliveries }\end{array}$ \\
\hline $\begin{array}{l}\text { Shawki and } \\
\text { Igarashi }{ }^{63}\end{array}$ & Danazol IUD & 9 & & & 6 months & spontaneous & 2 pregnancies \\
\hline Fujishita et al. $_{84}$ & $\begin{array}{l}\text { Conservative } \\
\text { surgery }\end{array}$ & 6 & & - & $\sim 4$ months & spontaneous & $\begin{array}{l}1 \text { clinical } \\
\text { pregnancy }\end{array}$ \\
\hline Wang et al. ${ }^{107}$ & $\begin{array}{l}\text { Conservative } \\
\text { surgery }\end{array}$ & & & $\begin{array}{l}4 \text { years } \\
\text { (secondary } \\
\text { infertility) } \\
\end{array}$ & 30 months & spontaneous & $\begin{array}{l}\text { Cesarean } \\
\text { section at term }\end{array}$ \\
\hline Wang et al. ${ }^{107}$ & $\begin{array}{l}\text { Combined } \\
\text { therapy } \\
(\text { danazol) }\end{array}$ & 1 & 38 & $\begin{array}{l}9 \text { years } \\
\text { secondary } \\
\text { infertility }\end{array}$ & 21 months & spontaneous & $\begin{array}{l}\text { Cesarean } \\
\text { section at term }\end{array}$ \\
\hline $\begin{array}{l}\text { Takeuchi et al. } \\
108\end{array}$ & $\begin{array}{l}\text { Conservaituve } \\
\text { surgery and } \\
\text { hysteroplasty }\end{array}$ & 8 & 28 to 39 & $1-5$ years & - & spontaneous & $\begin{array}{l}2 \text { clinical } \\
\text { pregnancies }\end{array}$ \\
\hline $\begin{array}{l}\text { Rabinovici et } \\
\text { al. } 75\end{array}$ & MRgFUS & 1 & 36 & $\begin{array}{l}\text { Secondary } \\
\text { infertility }\end{array}$ & 3 months & spontaneous & $\begin{array}{l}\text { Vaginal } \\
\text { delivery with } \\
\text { manual } \\
\text { extraction of } \\
\text { the placenta }\end{array}$ \\
\hline Landi et al. ${ }^{109}$ & $\begin{array}{l}\text { Laparoscopic } \\
\text { surgery } \\
\text { treated for } \\
\text { endometriosis }\end{array}$ & 26 & $\begin{array}{l}33.0 \\
\pm 4.3\end{array}$ & - & $\begin{array}{l}<30 \\
\text { months }\end{array}$ & spontaneous & $\begin{array}{l}3 \text { spontaneous } \\
\text { clinical } \\
\text { pregnancies }\end{array}$ \\
\hline
\end{tabular}




\begin{tabular}{|c|c|c|c|c|c|c|c|}
\hline Wang et al. ${ }^{79}$ & $\begin{array}{l}\text { GnRHa (6 } \\
\text { months) }\end{array}$ & 37 & $\begin{array}{l}32.7 \\
\pm 1.4\end{array}$ & $>3$ years & $\begin{array}{l}<12 \\
\text { months }\end{array}$ & spontaneous & $\begin{array}{l}4 \text { pregnancies } \\
\text { with } 3 \\
\text { successful } \\
\text { deliveries }\end{array}$ \\
\hline Wang et al. ${ }^{79}$ & $\begin{array}{l}\text { Conservative } \\
\text { surgery or } \\
\text { combined } \\
\text { therapy }\end{array}$ & 28 & $\begin{array}{l}34.3 \pm \\
2.1\end{array}$ & $>3$ years & 36 months & spontaneous & $\begin{array}{l}13 \\
\text { pregnancies } \\
\text { with } 9 \\
\text { deliveries }\end{array}$ \\
\hline Wang et al. ${ }^{89}$ & $\begin{array}{l}\text { Conservative } \\
\text { surgery }\end{array}$ & 51 & $\begin{array}{l}37.0 \pm \\
4.8\end{array}$ & - & $\begin{array}{l}<24 \\
\text { months }\end{array}$ & - & $\begin{array}{l}20 \text { clinical } \\
\text { pregnancies } \\
\text { with } 17 \\
\text { successful } \\
\text { deliveries }\end{array}$ \\
\hline Wang et al. ${ }^{89}$ & $\begin{array}{l}\text { Combined } \\
\text { therapy } \\
\text { (GnRHa) }\end{array}$ & 114 & $\begin{array}{l}38.9 \pm \\
3.8\end{array}$ & - & $\begin{array}{l}3-22 \\
\text { months }\end{array}$ & & $\begin{array}{l}35 \text { clinical } \\
\text { pregnancies } \\
\text { with } 32 \\
\text { successful } \\
\text { deliveries }\end{array}$ \\
\hline$\underset{110}{\text { Al Jama et al. }}$ & $\begin{array}{l}\text { GnRHa (6 } \\
\text { months) }\end{array}$ & 22 & $\begin{array}{l}34.3 \pm \\
4.6\end{array}$ & $6-15$ years & $\begin{array}{l}5-18 \\
\text { months }\end{array}$ & - & $\begin{array}{l}\text { 1 spontaneous } \\
\text { abortion, } 1 \\
\text { ectopic } \\
\text { pregnancy, } 1 \\
\text { vaginal } \\
\text { delivery at } \\
\text { term }\end{array}$ \\
\hline$\underset{110}{\text { Al Jama et al. }}$ & $\begin{array}{l}\text { Combined } \\
\text { therapy } \\
\text { (GnRHa) }\end{array}$ & 18 & $\begin{array}{l}38.1 \pm \\
0.9\end{array}$ & $6-15$ years & $\begin{array}{l}4-30 \\
\text { months }\end{array}$ & - & $\begin{array}{l}2 \text { spontaneous } \\
\text { abortion, } 6 \\
\text { cesaren } \\
\text { section }\end{array}$ \\
\hline Osada et al. ${ }^{111}$ & $\begin{array}{l}\text { Conservative } \\
\text { surgery }\end{array}$ & 26 & & - & - & $\begin{array}{l}\text { spontaneous } \\
\text { (4), ART } \\
(12)\end{array}$ & $\begin{array}{l}16 \text { clinical } \\
\text { pregnancies, } \\
14 \text { cesarean } \\
\text { section at } \\
\text { term, } 2 \\
\text { spontaneous } \\
\text { abortion at } \\
16 \mathrm{w} \text { and } 5 \mathrm{w}\end{array}$ \\
\hline Huang et al. ${ }^{91}$ & $\begin{array}{l}\text { Combined } \\
\text { therapy } \\
\text { (GnRHa) }\end{array}$ & 9 & 31 to 37 & $>3$ years & $\begin{array}{l}62-83 \\
\text { months }\end{array}$ & ART & $\begin{array}{l}3 \text { clinical } \\
\text { pregnancies } \\
\text { with } 2 \\
\text { cesarean } \\
\text { sections at } \\
\text { term }\end{array}$ \\
\hline Kishi et al. ${ }^{90}$ & $\begin{array}{l}\text { Conservative } \\
\text { surgery }\end{array}$ & 102 & 26 to 51 & 3-6 years & $\begin{array}{l}<92 \\
\text { months }\end{array}$ & $\begin{array}{l}\text { spontaneous } \\
\text { and ART }\end{array}$ & $\begin{array}{l}\text { Clinical } \\
\text { pregnancy rate } \\
41.3 \% \text { in } \\
\text { women aged } \\
39 \text { years or } \\
\text { younger and } \\
3.9 \% \text { in }\end{array}$ \\
\hline
\end{tabular}




\begin{tabular}{|l|l|l|l|l|l|l|l|}
\hline & & & & & & $\begin{array}{l}\text { women aged } \\
40 \text { years or } \\
\text { older }\end{array}$ \\
\hline $\begin{array}{l}\text { Saremi } \text { et al. } \\
112\end{array}$ & $\begin{array}{l}\text { Conservative } \\
\text { surgery }\end{array}$ & 70 & $\begin{array}{l}37.46 \pm \\
5.37\end{array}$ & $\sim 6$ years & $\begin{array}{l}\text { clinical } \\
\text { pregnancies, } \\
16 \text { live births: } \\
4 \text { spontaneous } \\
\text { abortions, } 1 \\
\text { still birth }\end{array}$ \\
\hline
\end{tabular}

